\title{
EFFECT OF SPLIT NITROGEN APPLICATIONS ON DURUM WHEAT CULTIVARS IN VOLCANIC SOIL
}

\author{
Juan Hirzel $^{1 *}$, Iván Matus', and Ricardo Madariaga ${ }^{1}$
}

\begin{abstract}
Durum wheat (Triticum turgidum L. var. durum) is an important crop for the world population and occupies a large cultivated area worldwide. New cultivars need constant improvement of their agronomic management, within which $\mathrm{N}$ fertilization is highlighted. Durum wheat is also important in Chile where genetic breeding and agronomic management have been developed to increase yield, industrial, and nutritional grain quality. The objective of this experiment was to determine the appropriate number of $\mathrm{N}$ applications during a crop cycle in a volcanic ash soil in South Central Chile. Nitrogen split applications were carried out on three durum wheat cultivars in a Melanoxerands soil during the 2003-2004 and 2004-2005 seasons. A rate of $200 \mathrm{~kg} \mathrm{ha}^{-1} \mathrm{~N}$ was applied at different growing stages including planting, tillering, flag leaf, and heading (200-0-0-0, 100-100-0-0, 66-67-67-0, and 50-50-50-50 kg N ha-1, respectively). The evaluated traits were grain yield, hectoliter weight, and wet gluten content. Results indicated that the use of two and three split $\mathrm{N}$ applications increased grain yield and wet gluten content with differences among genotypes. The best $\mathrm{N}$ split strategy corresponded to two and three $\mathrm{N}$ splits: at planting and tillering; at planting, tillering, and flag leaf, respectively.
\end{abstract}

Key words: durum wheat, cultivars, nitrogen, split applications, Triticum turgidum var. durum, volcanic soil.

\section{INTRODUCTION}

Durum wheat (Triticum turgidum L. var. durum) has become an important crop adapted to soil and climatic conditions in South Central Chile. Initially, this crop was mainly cultivated in the central zone of the country, but the higher profitability of fruit orchards and vineyards generated a reduction of the cultivated area and a shift in durum wheat area southward. As a consequence, national hectareage decreased from 28743 ha in 1997 to 10617 ha in 2007 (INE, 2007), of which 4956 (46.7\%) corresponded to volcanic ash soils located in the south central zone. The grain price currently paid by the durum wheat industry is 7\% higher than for bread wheat (Triticum aestivum L.), thus making it very attractive for farmers.

Since the principal area cultivated with durum wheat was the central zone (non-volcanic soil), agronomic management is not replicable in volcanic ash soils of the south central zone. Nitrogen fertilization is a practice

${ }^{1}$ Instituto de Investigaciones Agropecuarias INIA, Av. Vicente Méndez 515, Chillán, Chile. *Corresponding author (jhirzel@inia.cl). Received: 23 March 2010.

Accepted: 5 June 2010. which produces highly variable results for bread and durum wheat in non-volcanic soils (Kelley and Sweeney, 2007; Subedy et al., 2007; May et al., 2008). In addition, $\mathrm{N}$ cycle in soil generates variations in availability and recovery efficiency for plants (Cogger et al., 2001; McNeill et al., 2005; Hirzel et al., 2007) regarding the dynamics and interactions with chemical, physical, and biological soil properties (Mengel, 1996; De Vos et al., 2000; McDonald, 2006), with soil biomass, fertilization, plant, and environment (Bonde et al., 1988; Burger and Jackson, 2004; Chu et al., 2005). The rate and number of $\mathrm{N}$ applications affect both yield and grain quality (Subedy et al., 2007) which are the main factors affecting crop profitability. In this respect, studies conducted in Chilean volcanic ash soils with bread wheat indicated that $\mathrm{N}$ rates allowing yield maximization fluctuate between 150 and $200 \mathrm{~kg} \mathrm{ha}^{-1}$ with two to three split applications which generate an uptake of 98 to $128 \mathrm{~kg} \mathrm{~N}^{-1}$ for different tilling systems and crop rotations (Rouanet et al., 2001; Zagal et al., 2003). However, there are no similar studies for durum wheat in this type of soils and climatic conditions. A 2-yr experiment was conducted in order to determine the appropriate number of $\mathrm{N}$ applications for a durum wheat crop cycle planted in a volcanic ash soil in South Central Chile. 


\section{MATERIALS AND METHODS}

\section{Site, soil, and treatments}

Experiments were conducted over the 2003-2004 and 2004-2005 crop cycles at the Santa Rosa Experimental Station (71 $54^{\circ}$ ' S; 36 $31^{\circ}$ ' W; 220 m.a.s.l.) of the Instituto de Investigaciones Agropecuarias (INIA) located in South Central Chile. The climate is Mediterranean with a cold and rainy season in winter and a warm and dry summer. The long-term mean annual rainfall at the site is $800 \mathrm{~mm}$, mainly concentrated between May and September. The ash soil corresponds to Melanoxerands (CIREN, 1999) and consists of a depth of $0.8 \mathrm{~m}$ silt loam. The crop rotation for both experiments, and in both years, was legumesoat-wheat. A rate of $200 \mathrm{~kg} \mathrm{ha}^{-1} \mathrm{~N}$ (urea) was applied to the semi-dwarf durum wheat (Triticum turgidum $\mathrm{L}$. var. durum) cvs. Llareta-INIA, Corcolén-INIA, and QueuleINIA; the first two are the main cultivars in Chile. The rate of $\mathrm{N}$ was split in various ratios for planting, tillering, flag leaf, and heading: 200-0-0-0, 100-100-0-0, 67-6767-0, and 50-50-50-50 kg N ha- ${ }^{-1}$. The experimental design was a randomized complete block in a split-split plot arrangement with four replicates. Treatments and years were assigned to the principal plot whereas $\mathrm{N}$ split applications to the sub-plot, and cultivars to sub-subplots.

Soil samples were collected at three depths $(0-20$, 20-40, 40-60 cm) before planting. Soil chemical analysis indicated limitations only for $\mathrm{K}$ and $\mathrm{Mg}$, medium $\mathrm{P}$ and $\mathrm{Ca}$ content, as well as high organic matter and $\mathrm{S}$ content (Table 1).

\section{Crop management}

Each experimental unit consisted of six 2-m long rows spaced $0.2 \mathrm{~m}$ between rows. Sowing of the experiment was on 27 August 2004 and 17 August 2005 at a seed rate of $220 \mathrm{~kg} \mathrm{ha}^{-1}$. The seed bed was prepared by plowing to a depth of $30 \mathrm{~cm}$ followed by surface cultivation in both seasons. Before sowing, $120 \mathrm{~kg} \mathrm{ha}^{-1} \mathrm{P}_{2} \mathrm{O}_{5}$ and $80 \mathrm{~kg}$ $\mathrm{ha}^{-1} \mathrm{~K}_{2} \mathrm{O}$ fertilizer were applied (triple superphosphate and potassium chloride). Irrigation was employed three times in 2003 and 2004 at the booting, heading, and milk to dough stages as a complement to accumulated rainfall between July and December of each year (417 and 528 $\mathrm{mm}$, respectively). Irrigation events applied $50 \mathrm{~mm}$ which was enough to keep the soil adequately humid for crop development. Iodosulfuron-methyl-sodium herbicide was applied at a rate of $300 \mathrm{~g} \mathrm{ha}^{-1}$ at the early tillering stage to control graminaceous and dicotyledonous weeds. Incidence of disease and insects was low and no foliar fungicides or insecticides were applied.

Plots were harvested on 3 January 2004 and 5 January 2005. Yield was estimated from a 2-m long sample of four rows from each plot. Hectoliter weight and wet gluten content were determined from the grain collected in this sample. Wet gluten was determined with $10 \mathrm{~g}$ of pure flour to which 5.5 to $6.0 \mathrm{~mL}$ of $2 \%$ saline solution were added. The mixture was homogenized and placed in a gluten washer (Promylograph type TIK, Austria) and washed with a $2 \%$ of saline solution for $5 \mathrm{~min}$. This resulted in a protein product with an elastic consistency insoluble in water which was weighed on a precision scale. This weight was a percentage of the flour weight in

Table 1. Initial soil chemical and physical parameters of experimental site.

\begin{tabular}{|c|c|c|c|}
\hline \multirow[b]{2}{*}{ Parameters } & \multicolumn{3}{|c|}{ Depth $(\mathbf{c m})$} \\
\hline & 0 to 20 & 20 to 40 & 40 to 60 \\
\hline Bulk density, $\mathrm{g} \mathrm{cm}^{-3}$ & 1.20 & 1.25 & 1.30 \\
\hline Total porosity, $\%$ & 54.72 & 52.83 & 50.94 \\
\hline Water retention to 0.33 bars, $\%$ & 30.02 & 25.42 & 20.04 \\
\hline Water retention to 15 bars, $\%$ & 15.17 & 13.44 & 12.15 \\
\hline $\mathrm{pH}$ & 6.5 & 6.5 & 6.7 \\
\hline Organic matter, $\%$ & 6.1 & 6.0 & 2.6 \\
\hline Inorganic $\mathrm{N}, \mathrm{mg} \mathrm{kg}^{-1}$ & 15 & 14 & 5 \\
\hline P-Olsen, mg kg-1 & 11 & 11 & 6 \\
\hline Exchangeable $\mathrm{K}, \mathrm{cmol}_{(+)} \mathrm{kg}^{-1}$ & 0.22 & 0.25 & 0.12 \\
\hline Exchangeable $\mathrm{Ca}, \mathrm{cmol}_{(+)} \mathrm{kg}^{-1}$ & 5.81 & 5.31 & 2.12 \\
\hline Exchangeable $\mathrm{Mg}, \mathrm{cmol}_{(+)} \mathrm{kg}^{-1}$ & 0.44 & 0.42 & 0.32 \\
\hline Exchangeable $\mathrm{Na}, \mathrm{cmol}_{(+)} \mathrm{kg}^{-1}$ & 0.06 & 0.04 & 0.11 \\
\hline Exchangeable $\mathrm{Al}, \mathrm{cmol}_{(+)} \mathrm{kg}^{-1}$ & 0.04 & 0.04 & 0.03 \\
\hline Available $\mathrm{S}, \mathrm{mg} \mathrm{kg}^{-1}$ & 12.75 & 13.17 & 26.61 \\
\hline
\end{tabular}


the original sample. Hectoliter weight (HW) is the weight of grains contained in $100 \mathrm{~L}$. It was determined with an L. Schopper scale of $0.25 \mathrm{~L}$, and the results were expressed in $\mathrm{kg} \mathrm{hL}^{-1}$.

Results were examined by ANOVA and the least significant difference (LSD) test $(\mathrm{P}=0.05)$ following the SAS general model procedure (SAS Institute, 1989). Since ANOVA indicated no interaction for grain yield and wet gluten content between the sources of variation, a pool data analysis was performed (considering both seasons). These analyses were conducted for grain yield and wet gluten content.

\section{RESULTS AND DISCUSSION}

Grain yield showed differences between cultivars and split $\mathrm{N}$ application $(\mathrm{p}<0.01)$, but it was not affected by the crop cycle year (Table 2). Since there are no similar experiments performed in this type of soils, available information for non-volcanic soils is used as a reference. Subedy et al. (2007) reported the effects of $\mathrm{N}$ rates and split applications on grain yield and protein content of bread wheat cultivated in sandy loam and clay loam soils. Grain yield fluctuated between 7.68 and $8.41 \mathrm{Mg} \mathrm{ha}^{-1}$ (Figures 1 and 2) which was higher than that indicated by May et al. (2008) for durum wheat fertilized with lower $\mathrm{N}$ rates $\left(41.5,85\right.$, and $\left.140 \mathrm{~kg} \mathrm{~N}^{-1}\right)$, but similar to that indicated by some authors for bread wheat in similar soil and climate conditions (Mellado, 2000; Campillo et al., 2007). There was also no interaction between the sources of variations analyzed. Analysis of the individual effect indicates that both cultivars affect grain yield in durum wheat and split $\mathrm{N}$ applications. Analysis indicates that the cultivars with the highest yields in both years were Llareta-INIA and Corcolén-INIA (Figure 1). Furthermore,

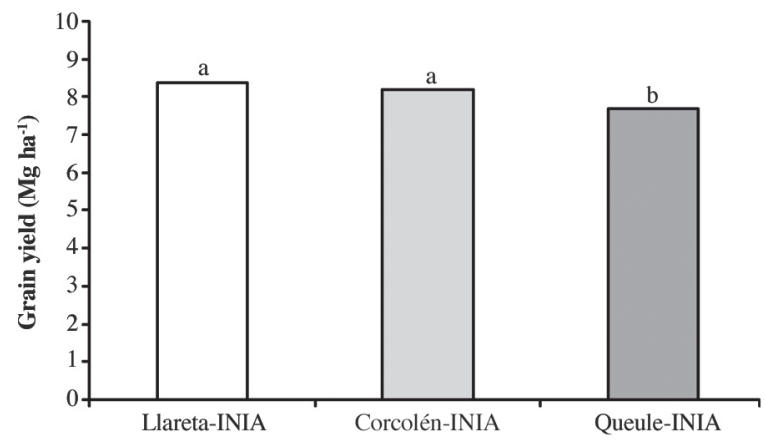

Different letters over the bars indicate differences among cultivars according to LSD test $(\mathrm{p}<0.05)$.

Pool data was generated using all $\mathrm{N}$ split applications for each cultivar.

Figure 1. Grain yield obtained during a 2-yr experiment for three durum wheat cultivars. the highest grain yield was obtained with two and three $\mathrm{N}$ split applications (Figure 2) as indicated by Subedy et al. (2007) in relation to the dynamics of $\mathrm{N}$ in the soil and with the particularities of volcanic soils (Rouanet et al., 2001; Zagal et al., 2003). A two-season average for cvs. LlaretaINIA and Corcolén-INIA showed a grain yield of 0.71 and $0.50 \mathrm{Mg} \mathrm{ha}^{-1}$, respectively, both significantly higher than cv. Queule-INIA ( $<$ 0.05) (Figure 1). Grain yield was 0.63 and $0.43 \mathrm{Mg} \mathrm{ha}^{-1}$, respectively, using two and three split $\mathrm{N}$ applications which were significantly higher than one $\mathrm{N}$ application $(\mathrm{p}<0.05)$ (Figure 2). There were no differences between one or three $\mathrm{N}$ splits $(\mathrm{p}>0.05)$ because of the high $\mathrm{N}$ rate used and the high soil organic matter content (Table 1). In addition, one $\mathrm{N}$ split produced a grain yield of $0.17 \mathrm{Mg} \mathrm{ha}^{-1}$ which was higher than the yield with four splits (Figure 2), but both treatments were significantly equal $(\mathrm{p}>0.05)$. As a consequence, results suggest that to improve grain yield in durum wheat, $\mathrm{N}$ application in two or three splits (planting and tillering; or planting, tillering, and flag leaf) could be the recommended management strategy for soil and climate conditions similar to those found in the experimental site.

Hectoliter weight fluctuated between 85.2 and $85.5 \mathrm{~kg}$ $\mathrm{hL}^{-1}$ (dates not shown), but statistical analysis indicates that this parameter was influenced by the crop cycle year $(\mathrm{p}<0.0001)$ (Table 2). Hectoliter weight was higher than that indicated by May et al. (2008). Even though there were no differences among $\mathrm{N}$ split applications or cultivars, values were outstanding according to the pasta industry requirements. This trait is strongly influenced by the cultivar's genetic background. Campillo et al. (2010) indicated that this parameter in bread wheat was affected

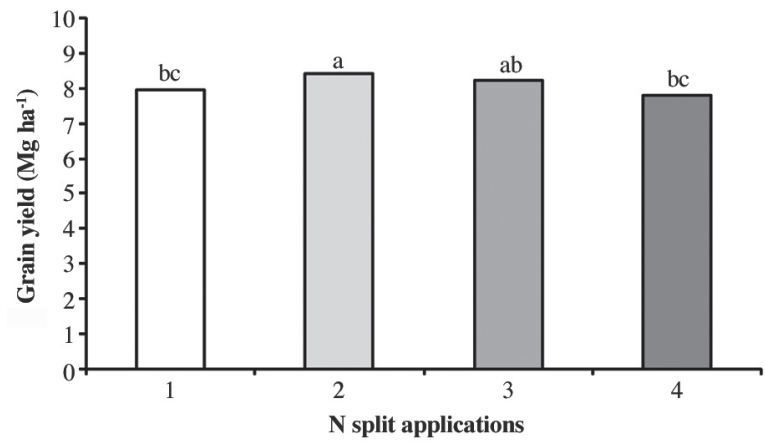

Different letters over the bars indicate differences among $\mathrm{N}$ split treatments according to LSD test $(\mathrm{p}<0.05)$.

$\mathrm{N}$ rate was split into various ratios at planting, tillering, flag leaf, and heading: 200-0-0-0, 100-100-0-0, 67-67-67-0, and 50-50-50-50 $\mathrm{kg} \mathrm{N} \mathrm{ha}^{-1}$.

Pool data was generated using all cultivars for each $\mathrm{N}$ split application.

Figure 2. Effect of four $\mathbf{N}$ split applications on grain yield of three durum wheat cultivars during a 2-yr study. 
Table 2. Statistical analysis of crop cycle year and $\mathrm{N}$ split effect on grain yield, hectoliter weight, and wet gluten content of three durum wheat cultivars.

\begin{tabular}{|c|c|c|c|c|c|c|c|}
\hline \multirow{2}{*}{$\begin{array}{l}\text { Source of } \\
\text { variation }\end{array}$} & \multirow[b]{2}{*}{ DF } & \multicolumn{2}{|c|}{ Grain yield } & \multicolumn{2}{|c|}{ Hectoliter weight } & \multicolumn{2}{|c|}{ Wet gluten content } \\
\hline & & Mean Square & $\operatorname{Pr}>F$ & Mean Square & $\operatorname{Pr}>\mathbf{F}$ & Mean Square & $\operatorname{Pr}>\mathbf{F}$ \\
\hline Year & 1 & 35.2837500 & 0.3617 & 13.03163438 & $<0.0001$ & 336.0390844 & 0.0002 \\
\hline Cultivar & 2 & 426.3707292 & 0.0002 & 0.02512917 & 0.8959 & 86.9179198 & 0.0206 \\
\hline Year x Cultivar & 2 & 12.3153125 & 0.7455 & 0.81915000 & 0.0344 & 0.5439656 & 0.9742 \\
\hline $\mathrm{N}$ split & 3 & 187.6202778 & 0.0069 & 0.49662049 & 0.1014 & 104.6941455 & 0.0038 \\
\hline Year x N split & 3 & 104.2006944 & 0.0693 & 0.37274549 & 0.1924 & 53.9139372 & 0.0621 \\
\hline Cultivar x N split & 6 & 51.9893403 & 0.2975 & 0.12021944 & 0.7854 & 17.9559142 & 0.5279 \\
\hline Year x Cultivar x N split & 6 & 50.6664236 & 0.3130 & 0.18807361 & 0.5562 & 10.6856934 & 0.7954 \\
\hline
\end{tabular}

DF: Degree of freedom.

by higher $\mathrm{N}$ rates, even higher than the rates evaluated in this experiment.

All sources of variation generated a statistical effect on the wet gluten (Table 2) parameter $(\mathrm{p}<0.05)$ and there was no interaction among them. Pool data analysis indicates that the cultivar with the highest wet gluten content was Llareta-INIA $(\mathrm{p}<0.05)$ (Figure 3$)$. This parameter was affected by the crop cycle year, as was indicated by Subedy et al. (2007) and Mellado (2000) for bread wheat. Results of this experiment indicated that gluten in grain is positively affected by four $\mathrm{N}$ split applications (Figure 4), and that this $\mathrm{N}$ fertilization strategy generates the highest gluten content $(\mathrm{p}<0.05)$. Mi et al. (2000) indicated similar effects for additional $\mathrm{N}$ applications during flowering which could increase $\mathrm{N}$ uptake and grain protein content in bread wheat, but the degree of the increase also depends on the cultivar. Likewise, Woolfolk et al. (2002) indicated that $\mathrm{N}$ fertilization before flowering was effective in increasing both grain yield and grain protein content. The use of three split $\mathrm{N}$ applications also

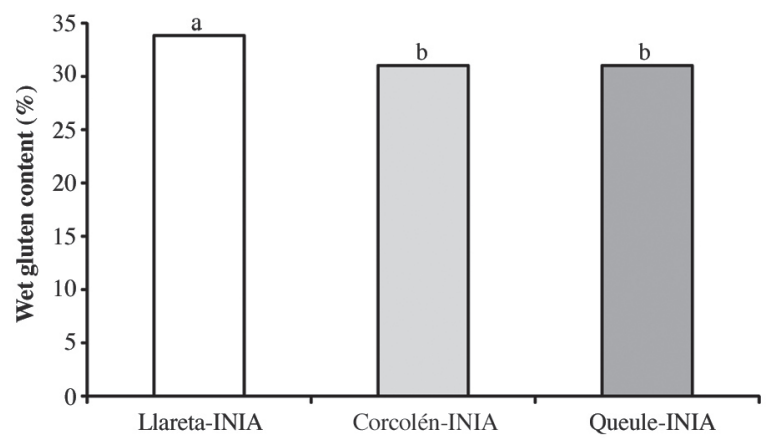

Different letters over the bars indicate differences among cultivars according to LSD test $(\mathrm{p}<0.05)$.

Pool data was generated using all $\mathrm{N}$ split applications for each cultivar.

Figure 3. Wet gluten content obtained during a 2-yr experiment for three durum wheat cultivars. generates a non-significant increment with respect to one application (Figure 4), this effect could be due to both the high $\mathrm{N}$ rate used and high soil organic matter content (Table 1).

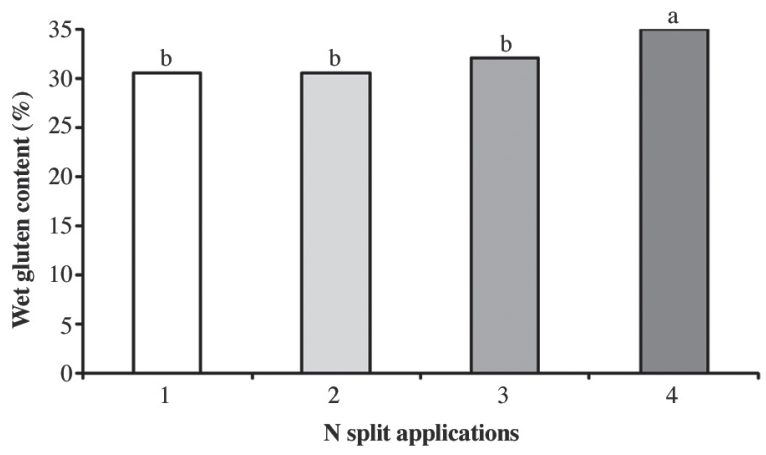

Different letters over the bars indicate differences among $\mathrm{N}$ split treatments according to LSD test $(\mathrm{p}<0.05)$.

$\mathrm{N}$ rate was split into various ratios at planting, tillering, flag leaf, and heading: 200-0-0-0, 100-100-0-0, 67-67-67-0, and 50-50-50-50 $\mathrm{kg} \mathrm{N} \mathrm{ha-1}$.

Pool data was generated using all cultivars for each $\mathrm{N}$ split application.

Figure 4. Effect of four $\mathbf{N}$ split applications on wet gluten content of three durum wheat cultivars during a 2-yr study.

\section{CONCLUSIONS}

Two and three split $\mathrm{N}$ applications contributed in increasing grain yield and wet gluten content of durum wheat. In contrast, hectoliter weight was not affected. The evaluated cultivars showed differences for grain yield and wet gluten content. The highest yield was in Llareta-INIA and Corcolén-INIA. The best strategy to maximize both grain yield and wet gluten content is to split $\mathrm{N}$ fertilization two or three times during the planting and tillering; planting, tillering and flag leaf stages, respectively. 


\section{RESUMEN}

Efecto de aplicaciones parcializadas de nitrógeno sobre cultivares de trigo candeal en un suelo volcánico. El trigo candeal (Triticum turgidum L. var. durum) es un alimento importante para la población mundial ocupando una amplia área de cultivo. Las nuevas variedades necesitan constantes ajustes en su manejo agronómico, dentro del cual destaca la fertilización nitrogenada. El trigo candeal es también importante en Chile, para el cual se ha desarrollado mejoramiento genético y manejo agronómico, con el objetivo de incrementar el rendimiento y calidad nutricional del grano. El objetivo de este experimento fue determinar el número adecuado de aplicaciones de $\mathrm{N}$ durante el ciclo del trigo candeal en un suelo volcánico del centro sur de Chile. Durante las temporadas 2003-2004 y 2004-2005 se realizaron experimentos de campo en un Melanoxerands, con aplicaciones parcializadas de $\mathrm{N}$ en tres variedades. Una dosis de $200 \mathrm{~kg} \mathrm{~N} \mathrm{ha}^{-1}$ fue aplicada en diferentes estados de crecimiento con combinaciones que consideraron siembra, inicio de macolla, hoja bandera y espigadura (200-0-0-0, 100-100-0-0, 66-67-67-0 y 50-50-50-50 kg N $\mathrm{ha}^{-1}$, respectivamente). Los parámetros evaluados fueron rendimiento de grano, peso del hectólitro y contenido de gluten. La aplicación de $\mathrm{N}$ en dos y tres parcialidades incrementó el rendimiento y contenido de gluten, con diferencias de rendimiento entre las variedades evaluadas. La mejor estrategia de parcialización de $\mathrm{N}$ correspondió a dos y tres parcialidades; en siembra e inicio de macolla; y en siembra, inicio de macolla y hoja bandera, respectivamente.

Palabras clave: trigo candeal, trigo duro, cultivares, nitrógeno, aplicación parcializada, Triticum turgidum L. var. durum, suelos volcánicos.

\section{LITERATURE CITED}

Bonde, T., J. Schnürer, and T. Rosswall. 1988. Microbial biomass as a fraction of potentially mineralizable nitrogen in soils from long-term field experiments. Soil Biology \& Biochemistry 20:447-452.

Burger, M., and L.E. Jackson. 2004. Plant and microbial nitrogen use and turnover: Rapid conversion of nitrate to ammonium in soil with roots. Plant and Soil 266:289-301.

Campillo, R., C. Jobet, y P. Undurraga. 2007. Optimización de la fertilización nitrogenada para trigo de alto potencial de rendimiento en Andisoles de la Región de La Araucanía, Chile. Agricultura Técnica 67:281-291.
Campillo, R., C. Jobet, and P. Undurraga. 2010. Effects of nitrogen on productivity, grain quality, and optimal nitrogen rates in winter wheat $\mathrm{cv}$. Kunpa-INIA in Andisols of Southern Chile. Chilean Journal of Agricultural Research 70:122-131.

Cogger, C.G., A.I. Bary, S.C. Fransen, and D.M. Sullivan. 2001. Seven years of biosolids versus inorganic nitrogen applications to tall fescue. Journal of Environmental Quality 30:2188-2194.

Chu, H.Y., Y. Hosen, K. Yagi, K. Okada, and O. Ito. 2005. Soil microbial biomass and activities in a Japanese Andisol as affected by controlled release and application depth of urea. Biology and Fertility of Soils 42:89-96.

CIREN. 1999. Descripciones de suelos materiales y símbolos: Estudio Agrológico VIII Región. Publicación CIREN $\mathrm{N}^{\circ} 121.583$ p. Centro de Información de Recursos Naturales CIREN, Santiago, Chile.

De Vos, J.A., D. Hesterberg, and P.A.C. Raats. 2000. Nitrate leaching in a tile-drained silt loam soil. Soil Science Society of America Journal 64:517-527.

Hirzel, J., I. Matus, F. Novoa, and I. Walter. 2007. Effect of poultry litter on silage maize (Zea mays L.) production and nutrient uptake. Spanish Journal of Agricultural Research 5:102-109.

INE. 2007. Censo Agropecuario 1997. Instituto Nacional de Estadísticas (INE), Santiago, Chile. Available at http://www.ine.cl/canales/chile_ estadistico/estadisticas_agropecuarias/xls/2005/ censoagropecuario.xls (accessed March 2010).

Kelley, K.W., and D.W. Sweeney. 2007. Placement of preplant liquid nitrogen and phosphorous fertilizer and nitrogen rate affects no-till wheat following different summer crops. Agronomy Journal 99:1009-1117.

May, W.E., M.R. Fernández, C.B. Holzapfel, and G.P. Lafond. 2008. Influence of phosphorous, nitrogen, and potassium chloride placement and rate on durum wheat yield and quality. Agronomy Journal 100:11731179 .

McDonald, C.K. 2006. Effect of soil properties on variation in growth, grain yield and nutrient concentration of wheat and barley. Australian Journal of Experimental Agriculture 46:93-105.

McNeill, A.M., J. Eriksen, L. Bergstrom, K.A. Smith, H. Marstorp, H. Kirchmann, and I. Nilsson. 2005. Nitrogen and sulphur management: Challenges for organic sources in temperate agricultural systems. Soil Use and Management 21:82-93.

Mellado, M. 2000. Genetic improvement in bread wheats (Triticum aestivum L.) in the South Central area of Chile: Analysis of grain yield and related variables in spring varieties. Chilean Journal of Agricultural Research 60:32-42. 
Mengel, K. 1996. Turnover of organic nitrogen in soils and its availability to crops. Plant and Soil 181:83-93.

Mi, G., L. Tang, F. Zhang, and J. Zhang. 2000. Is nitrogen after anthesis in wheat regulated by sink size? Field Crops Research 68:183-190.

Rouanet, J.L., I. Pino, A.M. Parada, and A. Nario. 2001. Effect of three soil tillage systems on physiological nitrogen use efficiency in wheat crop. Chilean Journal of Agricultural Research 61:459-469.

SAS Institute. 1989. Usage and reference. Version 6. 501 p. SAS Institute, Cary, North Carolina, USA.

Subedy, K.D., B.L. Ma, and A.G. Xue. 2007. Planting date and nitrogen effects on grain yield and protein content of spring wheat. Crop Science 47:36-44.
Woolfolk, C.W., W.R. Raun, G.V. Johnson, W.E. Thompson, R.W. Mullen, K.J. Wynn, and K.W. Freeman. 2002. Influence of late-season foliar nitrogen applications on yield and grain nitrogen in wheat. Agronomy Journal 94:429-434.

Zagal, E., N. Rodríguez, I. Vidal, and G. Hofmann. 2003. Nitrogen use efficiency and dynamics in a rotation with and without use of residues. Chilean Journal of Agricultural Research 63:298-310. 